\title{
Calcium Carbonate Packed Electrochemical Precipitation Column: New Concept of Phosphate Removal and Recovery
}

\author{
Yang Lei, ${ }^{*}, \dagger$, Santosh Narsing, ${ }^{\dagger}$ Michel Saakes, ${ }^{\dagger}$ Renata D. van der Weijden, ${ }^{*}, \dagger$ \\ and Cees J. N. Buisman ${ }^{\dagger,+}$

\begin{abstract}
${ }^{\dagger}$ Wetsus, Centre of Excellence for Sustainable Water Technology, P.O. Box 1113, 8900CC Leeuwarden, The Netherlands ${ }^{\ddagger}$ Department of Environmental Technology, Wageningen University and Research, P.O. Box 17, 6700AA Wageningen, The
\end{abstract} \\ Netherlands
}

\section{Supporting Information}

ABSTRACT: Phosphorus $(\mathrm{P})$ is a vital micronutrient element for all life forms. Typically, $\mathrm{P}$ can be extracted from phosphate rock. Unfortunately, the phosphate rock is a nonrenewable resource with a limited reserve on the earth. High levels of $P$ discharged to water bodies lead to eutrophication. Therefore, $\mathrm{P}$ needs to be removed and is preferably recovered as an additional $\mathrm{P}$ source. A possible way to achieve this goal is by electrochemically induced phosphate precipitation with coexisting calcium ions. Here, we report a new concept of phosphate removal and recovery, namely a $\mathrm{CaCO}_{3}$ packed electrochemical precipitation column, which achieved improved removal efficiency, shortened hydraulic retention time, and substantially enhanced stability, compared with our previous electrochemical system. The concept is based on the introduction of $\mathrm{CaCO}_{3}$ particles, which facilitates calcium phosphate precipitation by buffering the formed $\mathrm{H}^{+}$at the anode, releases $\mathrm{Ca}^{2+}$, acts as seeds, and establishes a high $\mathrm{pH}$ environment in the bulk solution in addition to that in the vicinity of the cathode. It was found that the applied current, the $\mathrm{CaCO}_{3}$ particle size, and the feed rate affect the removal of phosphate. Under optimized conditions (particle size, $<0.5 \mathrm{~mm}$; feed

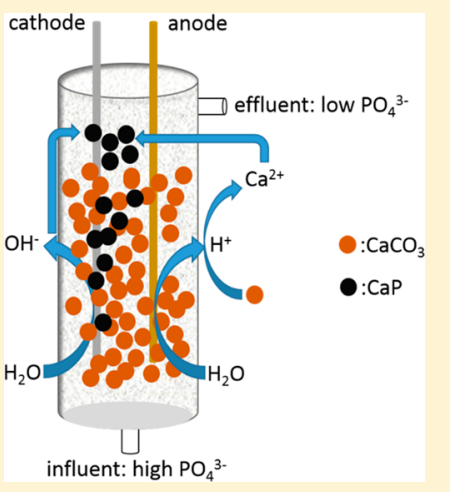
rate, $0.4 \mathrm{~L} / \mathrm{d}$; current, $5 \mathrm{~mA}$ ), in a continuous flow system, the $\mathrm{CaCO}_{3}$ packed electrochemical precipitation column achieved 90 $\pm 5 \%$ removal of phosphate in 40 days and $>50 \%$ removal over 125 days with little maintenance. The specific energy consumptions of this system lie between 29 and $61 \mathrm{kWh} / \mathrm{kg}$ P. The experimental results demonstrate the promising potential of the $\mathrm{CaCO}_{3}$ packed electrochemical precipitation column for P removal and recovery from P-containing streams.

\section{INTRODUCTION}

The ability to feed 10 billion people is one of the main challenges of the 21 st century. In any case, the use of phosphorus (P) fertilizer is crucial. $\mathrm{P}$, as an essential element for all living organisms, accounts for $2-4 \%$ of the weight of most dried cells and plays a vital role in fundamental biochemical reactions (i.e., gene expression). ${ }^{1}$ Typically, one adult consumes $35.2 \mathrm{~kg}$ of phosphate rock per year. ${ }^{2}$ In general, $\mathrm{P}$ fertilizer can be processed from mined phosphate rock. Unfortunately, phosphate rock, as a finite resource, will be subject to exhaustion in a few hundred years with the current mining and usage rate. ${ }^{3}$ The use of $\mathrm{P}$ fertilizer and other $\mathrm{P}$ products have brought much $\mathrm{P}$ to water bodies, leading to a worldwide environmental problem, namely, eutrophication. ${ }^{4,5}$

We need to address issues about $\mathrm{P}$ being scarce as a resource (fertilizer) yet abundant as a pollutant (eutrophication) by recycling the $\mathrm{P}$ in waste streams. ${ }^{4,5}$ Pioneers have recognized the importance of $P$ recycling and developed many approaches for achieving this goal., ${ }^{6,7}$ While each approach has its merits and drawbacks, the principle is the same: the conversion of $\mathrm{P}$ from a soluble form to a solid phase, which can then be separated from waste streams for potential reuse.
In the realm of $\mathrm{P}$ recovery, struvite process is a welldeveloped method. ${ }^{8}$ This method has the advantage that phosphate $\left(\mathrm{PO}_{4}-\mathrm{P}\right)$ and ammonium $\left(\mathrm{NH}_{4}-\mathrm{N}\right)$ are removed simultaneously. Also, the recovered product can be used as a slow release fertilizer. However, the struvite process needs wellcontrolled solution conditions, ${ }^{9}$ which typically means a high phosphate concentration, a $\mathrm{Mg} / \mathrm{NH}_{4} / \mathrm{PO}_{4}$ molar ratio close to 1:1:1, and $\mathrm{pH}$ between 8 and 9. ${ }^{10}$ As such, due to the low $\mathrm{Mg}^{2+}$ concentration relative to $\mathrm{PO}_{4}{ }^{3-}$ and $\mathrm{NH}_{4}{ }^{+}$in most nutrientrich waste streams, the dosing of a $\mathrm{Mg}$ source is required. ${ }^{10}$ The struvite process is used in practice but is not widely adopted.

Alternatively, $\mathrm{P}$ removal and recovery as calcium phosphate was proposed. ${ }^{11}$ This process has the advantage that the addition of $\mathrm{Ca}$ is usually not necessary as $\mathrm{Ca}^{2+}$ is an abundant ion in most waste streams. ${ }^{12,13}$ It is worth mentioning that even when $\mathrm{Ca}$ addition is required, the cost of dosing $\mathrm{Ca}$ is cheaper than dosing Mg. ${ }^{14,15}$ Moreover, calcium phosphate is the key component of mined phosphate rock and therefore, it

Received: June 26, 2019

Revised: August 14, 2019

Accepted: August 16, 2019

Published: August 16, 2019 
can be used directly as a raw material for producing $\mathrm{P}$ fertilizer in the existing production process. ${ }^{12}$ Furthermore, calcium phosphate has also recently been shown to be an effective fertilizer when compared to conventional fertilizers and struvite. $^{16}$

Electrochemical processes have gained increasing interest as next-generation wastewater treatment technologies in the last decades. ${ }^{17,18}$ On top of wastewater treatment; electrochemical methods also show excellent potential in resource recovery from waste streams. ${ }^{19,20}$ Lei and coauthors established and validated an electrochemical approach for $\mathrm{P}$ removal and recovery. ${ }^{13,21,22}$ This approach showed advantages: there was no need to dose a calcium source, adjust the $\mathrm{pH}$ of wastewater, or require a solid-liquid separation process. ${ }^{13,21,22}$ Moreover, it is a membrane-free system. However, the $\mathrm{P}$ removal efficiency in this system is low, and the retention time is long. For example, to reach $50 \%$ removal efficiency, a run-time of about $24 \mathrm{~h}$ at $20 \mathrm{~mA}$ (current density of $4.0 \mathrm{~A} / \mathrm{m}^{2}$ ) is needed. $^{23}$

One of the critical reasons for the low removal efficiency and long retention time in this membrane-free electrochemical approach is the recombination of anode produced protons $\left(\mathrm{H}^{+}\right)$with cathode generated hydroxide ions $\left(\mathrm{OH}^{-}\right)$. While the $\mathrm{H}^{+}-\mathrm{OH}^{-}$recombination can be avoided by using ion exchange membranes, the introduction of membranes will bring other problems, such as a complex configuration, the fouling of membranes, the associated maintenance effort, and the increased operating cost.

Here, in this paper, we propose a simple yet highly efficient approach to overcome direct $\mathrm{H}^{+}-\mathrm{OH}^{-}$recombination. In our approach, we fill a column-shaped electrochemical precipitation reactor with calcium carbonate $\left(\mathrm{CaCO}_{3}\right)$ particles. The $\mathrm{CaCO}_{3}$ particles, which are in contact with/or close to the anode, react with electrochemically produced $\mathrm{H}^{+},{ }^{24}$ and thus limit the neutralization between $\mathrm{H}^{+}$and $\mathrm{OH}^{-}$. Additionally, two extra benefits are achieved. Along with the consumption of $\mathrm{H}^{+}$by $\mathrm{CaCO}_{3}$ particles, $\mathrm{Ca}^{2+}$ ions are released into the bulk solution. Meanwhile, the electrochemically generated $\mathrm{OH}^{-}$ ions are accumulated in the bulk solution. As a result, a high $\mathrm{pH}$ environment can be established in the bulk solution as well as in the vicinity of the cathode. ${ }^{24}$ Therefore, homogeneous precipitation of calcium phosphate may occur in the bulk solution, in addition to its precipitation on the cathode surface. Furthermore, the $\mathrm{CaCO}_{3}$ particles may work as crystallization seeds, allowing calcium phosphate nucleation and growth on their surface at a much lower driving force and induction time. $^{25}$

The goal of this research is to identify the possibility, the efficiency, and the mechanism of the $\mathrm{CaCO}_{3}$ particle packed electrochemical precipitation column toward phosphate removal and recovery. We first looked at the possibility of electrochemically splitting of $\mathrm{CaCO}_{3}$ particles. We then explored the effects of particle size, feed rate, and electrical current on the removal of phosphate in this system. Additionally, we examined the feasibility of this system to treat low P-containing streams and real domestic wastewater and further evaluated the stability of this system for long-term operation. The $\mathrm{CaCO}_{3}$ packed electrochemical precipitation column may offer a robust yet efficient approach toward $\mathrm{P}$ removal and recovery from various wastewaters.

\section{MATERIALS AND METHODS}

Materials. $\mathrm{Na}_{2} \mathrm{HPO}_{4} \cdot 2 \mathrm{H}_{2} \mathrm{O}, \mathrm{NaOH}$, and $\mathrm{Na}_{2} \mathrm{SO}_{4}$ were purchased from VWR chemicals (Belgium). $\mathrm{Ca}\left(\mathrm{NO}_{3}\right)_{2} \cdot 4 \mathrm{H}_{2} \mathrm{O}$ was received from Merck (Germany). The $\mathrm{CaCO}_{3}$ particles were supplied by a drinking water company where $\mathrm{CaCO}_{3}$ solids were produced from the water softening process. These particles were fractioned through mesh sieves: diameters $<0.5$, $0.5-1,1-2$, and $2-3 \mathrm{~mm}$. The domestic wastewater was obtained from the influent of a local wastewater treatment plant (Leeuwarden, The Netherlands), further prefiltered with a $100 \mu \mathrm{m}$ sieve, and stored in a $4{ }^{\circ} \mathrm{C}$ fridge. The electrodes were provided by MAGNETO Special Anodes BV (Schiedam, The Netherlands).

Setup. Figure 1 shows the configuration of the electrochemical precipitation column with real images. The column

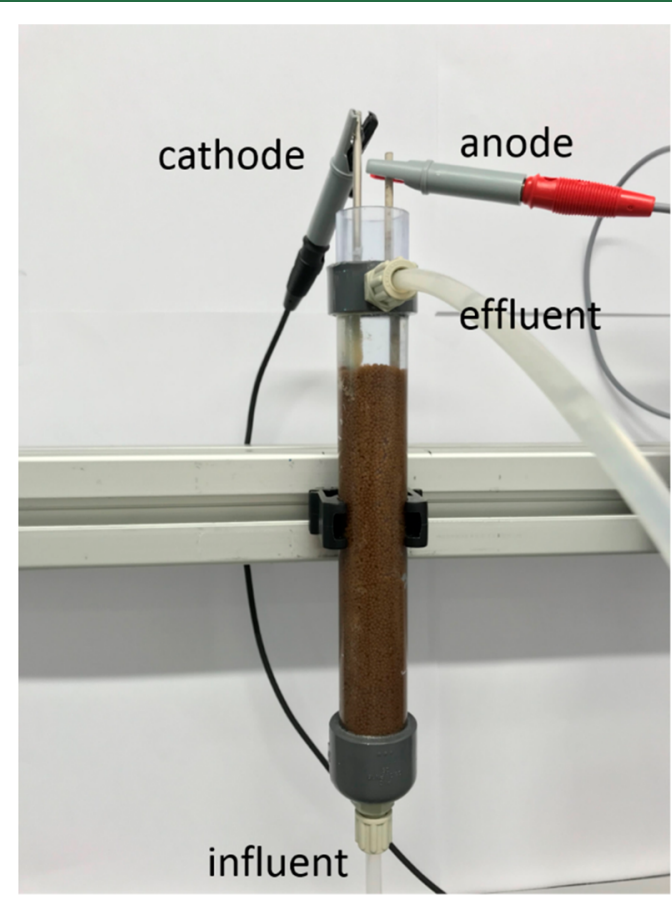

Figure 1. Schematic diagram of the setup. The cathode is A-grade titanium rod; the anode is platinum coated titanium rod. $\mathrm{CaCO}_{3}$ particles are packed in the column-shaped electrochemical cell. At the bottom of the column, glass beads are used.

was made of polypropylene material with a diameter of $6 \mathrm{~cm}$ and a length of $16 \mathrm{~cm}$ and had an empty bed volume of about $70 \mathrm{~mL}$. The column was filled with glass beads at the bottom to prevent clogging of the tubes with fine $\mathrm{CaCO}_{3}$ particles and to have an equal distribution of feed solution inside the column. There was about $85 \mathrm{~g}$ of a predetermined size (1-2 $\mathrm{mm}$ ) of $\mathrm{CaCO}_{3}$ particles on top of the glass beads, giving a bed height of $12-13 \mathrm{~cm}$. The column contained two rod-shaped electrodes, a platinum-coated titanium anode, and a pure Agrade titanium cathode. Both electrodes had diameters of 3 $\mathrm{mm}$ and lengths of about $20 \mathrm{~cm}$ each. However, only the electrode length that was below the liquid level was considered for the calculation of current density. Thus, the length was about $15 \mathrm{~cm}$ for both electrodes. Therefore, the surface area of both electrodes was approximately $0.0014 \mathrm{~m}^{2}$. The distance between the electrodes was about $1 \mathrm{~cm}$. The electrochemical precipitation column was operated under constant current mode, and the needed cell voltage was provided by a power 
supply (ES 030-5, Delta Electronics B.V, The Netherlands). All experiments were conducted at room temperature $(T=23$ $\left.\pm 1{ }^{\circ} \mathrm{C}\right)$.

Experimental Design. We first conducted experiments with synthetic solutions in the as-described electrochemical precipitation column. The typical synthetic solutions contained $0.6 \mathrm{mM} \mathrm{PO}_{4}-\mathrm{P}$ and $10 \mathrm{mM} \mathrm{Na}_{2} \mathrm{SO}_{4}$, which were prepared by dissolving analytical grade chemicals in deionized water (18.2 $\mathrm{M} \Omega \cdot \mathrm{cm}$, Millipore). We studied the influence of particle size $(<0.5,0.5-1,1-2,2-3 \mathrm{~mm})$, applied current $(5,10,20 \mathrm{~mA})$, and feed rate $(0.4,0.8,1.2,2.4 \mathrm{~L} / \mathrm{d})$ on the performance of the electrcochemical precipitation column with synthetic solutions. In the section of proof of principle, the feed solutions only contained $10 \mathrm{mM} \mathrm{Na}_{2} \mathrm{SO}_{4}$ and the $\mathrm{pH}$ was adjusted to 7.5 , which was the same as the phosphate present in the feed solution. In some experiments, we reduced the phosphate concentration to as low as $0.032 \mathrm{mM}\left(\sim 1.0 \mathrm{mg} / \mathrm{L} \mathrm{PO}_{4}-\mathrm{P}\right)$ in order to determine the feasibility of this system to treat low phosphate-containing solutions. We then evaluated the efficiency of this system toward real domestic wastewater. To identify the function of the $\mathrm{CaCO}_{3}$ particles, we also examined the removal of $\mathrm{PO}_{4}-\mathrm{P}$ in the absence of $\mathrm{CaCO}_{3}$ particles, by supplying $1.0 \mathrm{mM} \mathrm{Ca}{ }^{2+}(40 \mathrm{mg} / \mathrm{L})$ to the feed solution, and the adsorption of phosphate by $\mathrm{CaCO}_{3}$ particles in the absence of current. For each independent test, the column was run in a continuous up-flow way under predetermined conditions for at least 1 week. The data are given as the mean and standard deviations of the samples collected each day over the independent testing period. After each test, both electrodes were cleaned by immersion in acidic solutions ( $\left.1 \mathrm{M} \mathrm{HNO}_{3}\right)$ and then rinsed with deionized water. The new and used $\mathrm{CaCO}_{3}$ granule compositions were examined by dissolution in strong acid $\left(69 \% \mathrm{HNO}_{3}, 20 \mathrm{~mL}\right)$. The composition of these acidic solutions was analyzed to identify the possible precipitates on both electrodes and $\mathrm{CaCO}_{3}$ particles. Lastly, we tested the performance of the electrochemical precipitation column for phosphate removal under the recognized best parameters for a long period (125 days) in order to verify the stability of this system for long-term operation.

Analytical Methods. We applied ICP-AES (Optima 5300 $\mathrm{DV}$, PerkinElmer) to quantify the concentrations of $\mathrm{P}$ and $\mathrm{Ca}$, with the detection limits for P and Ca being 20 and $50 \mu \mathrm{g} / \mathrm{L}$, respectively. Total organic carbon (TOC) was measured by a TOC-LCPH analyzer equipped with an ASI-L autosampler (Shimadzu) with $1.0 \mathrm{mg} / \mathrm{L}$ detection limit. We identified the phases of the fresh (unused) and used $\mathrm{CaCO}_{3}$ granules by $\mathrm{X}$ ray diffraction (XRD) and determined their elemental compositions with acid digestion. Details about the instruments can be referred elsewhere. ${ }^{13,23}$

\section{RESULTS AND DISCUSSION}

Proof of Principle: Electrochemically Splitting of $\mathrm{CaCO}_{3}$ Particles. We first show that calcium ions can be released from electrochemically induced dissolution of $\mathrm{CaCO}_{3}$ particles (see solid characterization in Text S1, Figure S1, and Table S1). In this case, the feed solution only contained $\mathrm{Na}^{+}$ and $\mathrm{SO}_{4}{ }^{2-}\left(\right.$ no $\left.\mathrm{PO}_{4}{ }^{3-}\right)$. As shown in Figure 2, in the absence of current, the effluent $\mathrm{Ca}$ concentration was $8.7 \mathrm{mg} / \mathrm{L}$ and $\mathrm{pH}$ was 8.3. In the presence of $5 \mathrm{~mA}$ (current density of $3.5 \mathrm{~A}$ / $\mathrm{m}^{2}$ ), the effluent $\mathrm{Ca}$ concentration and $\mathrm{pH}$ increased to 28.0 $\mathrm{mg} / \mathrm{L}$ and 9.9, respectively. This reveals that the combination of $\mathrm{CaCO}_{3}$ particles with electric current not only provides calcium ions but also creates a high $\mathrm{pH}$ environment in the
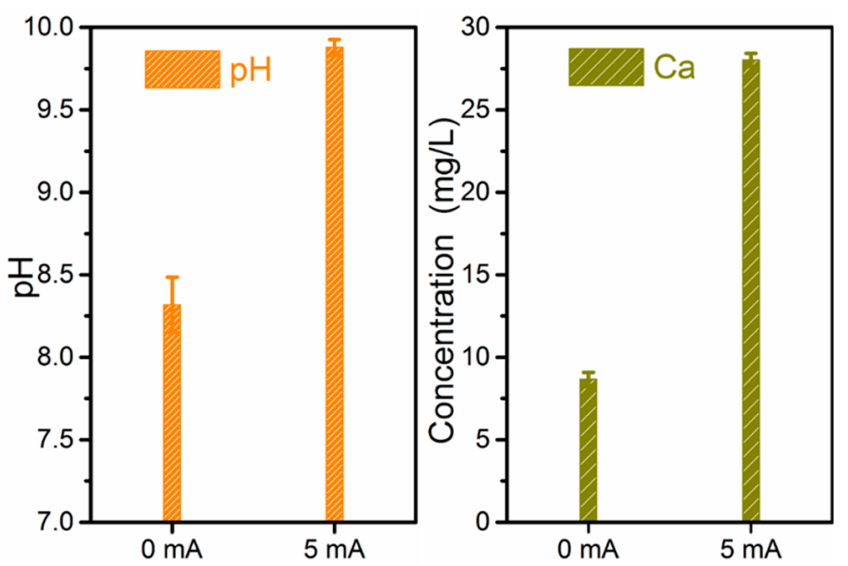

Figure 2. Proof of principle. Conditions: feed solutions contain only $10 \mathrm{mM} \mathrm{Na} \mathrm{SO}_{4}$ and no phosphate. Initial $\mathrm{pH}$ of feed solution was adjusted to 7.5 , which is similar to when phosphate is present.

entire bulk solution. In a typical electrochemical system, at the anode, water molecules are oxidized, producing $\mathrm{H}^{+}$and oxygen (eq 1). At the cathode, water molecules are reduced, forming $\mathrm{OH}^{-}$and hydrogen (eq 2).

$$
\begin{aligned}
& \text { Anode: } 2 \mathrm{H}_{2} \mathrm{O} \rightarrow 4 \mathrm{H}^{+}+\mathrm{O}_{2} \uparrow+4 \mathrm{e}^{-} \\
& \text {Cathode: } 4 \mathrm{H}_{2} \mathrm{O}+4 \mathrm{e}^{-} \rightarrow 4 \mathrm{OH}^{-}+2 \mathrm{H}_{2} \uparrow \\
& \text { Bulk solution: } \mathrm{H}^{+}+\mathrm{OH}^{-} \rightarrow \mathrm{H}_{2} \mathrm{O} \\
& \mathrm{CaCO}_{3}+2 \mathrm{H}^{+} \rightarrow \mathrm{Ca}^{2+}+\mathrm{H}_{2} \mathrm{CO}_{3}
\end{aligned}
$$

As a result, a local high $\mathrm{pH}$ and low $\mathrm{pH}$ will be established at the cathode and anode, respectively. The bulk solution $\mathrm{pH}$, however, will not change significantly, due to the neutralization of $\mathrm{H}^{+}$with $\mathrm{OH}^{-}$(eq 3 ). In the presence of $\mathrm{CaCO}_{3}$ particles, the $\mathrm{CaCO}_{3}$ solids which face the anode will be dissolved to some extent by the anodically produced acidity (eq 4). ${ }^{24}$ Along with the reaction of $\mathrm{H}^{+}$with $\mathrm{CaCO}_{3}$, the cathodically produced $\mathrm{OH}^{-}$ions will accumulate in the bulk solution, increasing the $\mathrm{pH}$ of the bulk solution. ${ }^{24}$ As a result, we found an increased $\mathrm{Ca}$ concentration and $\mathrm{pH}$ in the effluent (Figure 2). In the case of a feed solution containing phosphate, the phosphate will be removed by calcium phosphate precipitation, either on the cathode surface which has a local high $\mathrm{pH}$ or on the surface of $\mathrm{CaCO}_{3}$ particles (heterogeneous precipitation) and/or even in the bulk solution by homogeneous precipitation. It may be argued that $\mathrm{CaCO}_{3}$ granules can directly result in the removal of phosphate by adsorption. However, according to the control experiments in the absence of current, the removal of phosphate is negligible, and the effluent calcium concentration and $\mathrm{pH}$ are also much lower than those with current (Figure 3).

Effect of Current. We further studied the influence of current (density) on the performance of the electrochemical precipitation column. Figure 3 shows that the removal of phosphate strongly depends on the applied current. Specifically, in an open circuit $(0 \mathrm{~mA})$, only $4 \%$ of phosphate was removed. The phosphate removal efficiency reached $23 \%$ at a current of $5 \mathrm{~mA}\left(3.5 \mathrm{~A} / \mathrm{m}^{2}\right)$ and $40 \%$ at $10 \mathrm{~mA}\left(7.0 \mathrm{~A} / \mathrm{m}^{2}\right)$. However, a further increase of the applied current to $20 \mathrm{~mA}$ $\left(14 \mathrm{~A} / \mathrm{m}^{2}\right)$ did not promote the removal of phosphate anymore. This may be due to the competition between the precipitation of $\mathrm{CaCO}_{3}$ and calcium phosphate. In our 

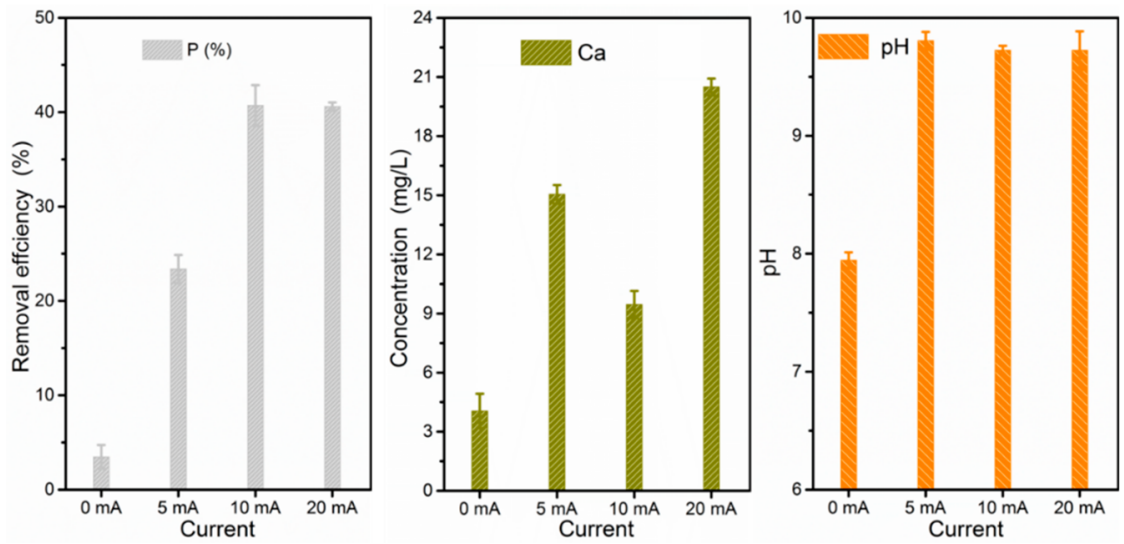

Figure 3. Effects of current on the removal of $\mathrm{PO}_{4}-\mathrm{P}$, the effluent Ca concentration, and $\mathrm{pH}$. Conditions: particle size, $1-2 \mathrm{~mm}$; feed rate, $2.4 \mathrm{~L} / \mathrm{d}$. Feed solution contains $10 \mathrm{mM} \mathrm{Na}_{2} \mathrm{SO}_{4}$, and $0.6 \mathrm{mM} \mathrm{PO}_{4}-\mathrm{P}$ with an initial $\mathrm{pH}$ of 7.5.

previous study, we found that in the presence of (bi)carbonate, a high current resulted in a greater precipitation of $\mathrm{CaCO}_{3}$ than calcium phosphate. ${ }^{13}$

The effluent $\mathrm{Ca}$ concentration is not always positively related to the applied current. At $10 \mathrm{~mA}$, the effluent $\mathrm{Ca}$ concentration $(9.5 \mathrm{mg} / \mathrm{L})$ was lower than that at $5 \mathrm{~mA}(15.1$ $\mathrm{mg} / \mathrm{L}$ ), which was not expected. This might result from the simultaneous release and consumption of $\mathrm{Ca}^{2+}$. While a high current means a high production of $\mathrm{H}^{+}$possibly resulting in a greater release of $\mathrm{Ca}^{2+}$ from $\mathrm{CaCO}_{3}$ particles, a high current also means a high removal of $\mathrm{P}$ and thus the removal of released $\mathrm{Ca}^{2+}$. More importantly, it should be noted that the calcium ions could precipitate with carbonate again by forming calcium carbonate (eq 5).

$$
\mathrm{Ca}^{2+}+\mathrm{CO}_{3}^{2-} \rightarrow \mathrm{CaCO}_{3}
$$

This is because the dissolution of $\mathrm{CaCO}_{3}$ solids will release both calcium ions and carbonic acid. ${ }^{24}$ The carbonic acid may quickly dissociate to bicarbonate and/or carbonate, depending on the bulk solution $\mathrm{pH}$ before it would escape as $\mathrm{CO}_{2}$ through the bulk solution. As the local $\mathrm{pH}$ close to the cathode is much higher than that in the bulk solution, ${ }^{23}$ part of the inorganic carbon around the cathode may be in the form of $\mathrm{CO}_{3}{ }^{2-}$, which may react with $\mathrm{Ca}^{2+}$, forming solid calcium carbonate. These factors together may explain the trend of effluent $\mathrm{Ca}$ concentration as a function of current.

The effluent $\mathrm{pH}$ was relatively stable around 9.7 in closed circuit, regardless of the applied current. As explained, the increase of effluent $\mathrm{pH}$ is due to the consumption of $\mathrm{H}^{+}$ (anode) by $\mathrm{CaCO}_{3}$ particles and the accumulation of $\mathrm{OH}^{-}$ (cathode). The relatively stable effluent $\mathrm{pH}$ is due to the formation of (bi)carbonate resulting from the electrochemically induced dissolution of $\mathrm{CaCO}_{3}$ granules, which work as buffer.

Effect of $\mathrm{CaCO}_{3}$ Particle Size. A prerequisite for the electrochemical precipitation of calcium phosphate in the $\mathrm{CaCO}_{3}$ packed column is the release of calcium ions. As such, the $\mathrm{CaCO}_{3}$ particle size is expected to affect the performance. In general, the smaller the particle size, the larger the surface area. Therefore, more release of calcium ions is expected when using smaller particles as is $\mathrm{P}$ removal efficiency. Indeed, as shown in Figure S2, the removal of P follows the theory that a smaller particle size results in a higher removal efficiency, except for the case of the particles with sizes from 2 to $3 \mathrm{~mm}$.
The 2-3 $\mathrm{mm} \mathrm{CaCO}_{3}$ particles are believed to have a lower surface area in comparison to smaller particles.

Nonetheless, we achieved the second highest removal efficiency $(35 \%)$ by using $2-3 \mathrm{~mm} \mathrm{CaCO}_{3}$ particles, which was not expected. This might be explained by large pores between the stacked $\mathrm{CaCO}_{3}$ particles with the use of bigger particles, which facilitates the diffusion of released $\mathrm{Ca}^{2+}$, and its interaction with phosphate and $\mathrm{CaCO}_{3}$ solids. Due to the presence of (bi)carbonate (buffer), the $\mathrm{pH}$ in the column should be similar to the effluent $\mathrm{pH}$, which lies between 9 and 10. The high $\mathrm{pH}$ may result in a homogeneous precipitation of calcium phosphate in the bulk solution inside the column and the associated settling down on the $\mathrm{CaCO}_{3}$ particles. Thus, a higher removal of phosphate was observed with $2-3 \mathrm{~mm}$ particles (35\%) than that with the use of $1-2 \mathrm{~mm}$ particles (21\%). Additionally, the use of large particles may bring practical benefits by reducing the clogging risk of the column in the treatment of real wastewater which would result in a longer run-time.

Effect of Feed Rate. Figure 4 shows that the removal efficiency of phosphate decreased with the increase of flow rate. At $0.4 \mathrm{~L} / \mathrm{d}$, the phosphate removal efficiency reached $87 \%$. The removal efficiency slightly decreased to $79 \%$ at 0.8
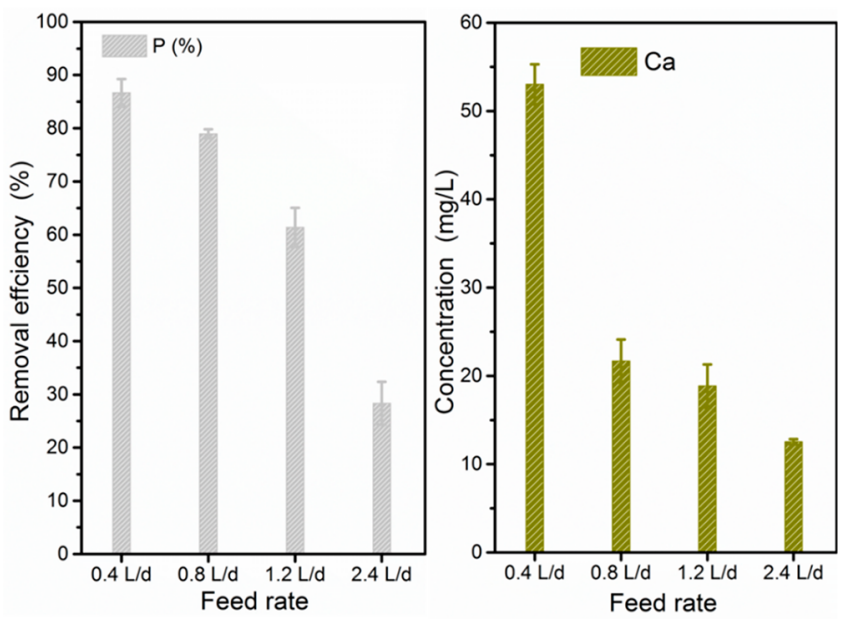

Figure 4. Effects of feed rate on the removal of $\mathrm{P}$ and the effluent $\mathrm{Ca}$ concentration. Conditions: particle size, 1-2 mm; current, $5 \mathrm{~mA}$ (current density $3.5 \mathrm{~A} / \mathrm{m}^{2}$ ). Feed solution contains $10 \mathrm{mM} \mathrm{Na}{ }_{2} \mathrm{SO}_{4}$ and $0.6 \mathrm{mM} \mathrm{PO}_{4}-\mathrm{P}$ with an initial $\mathrm{pH}$ of 7.5 . 

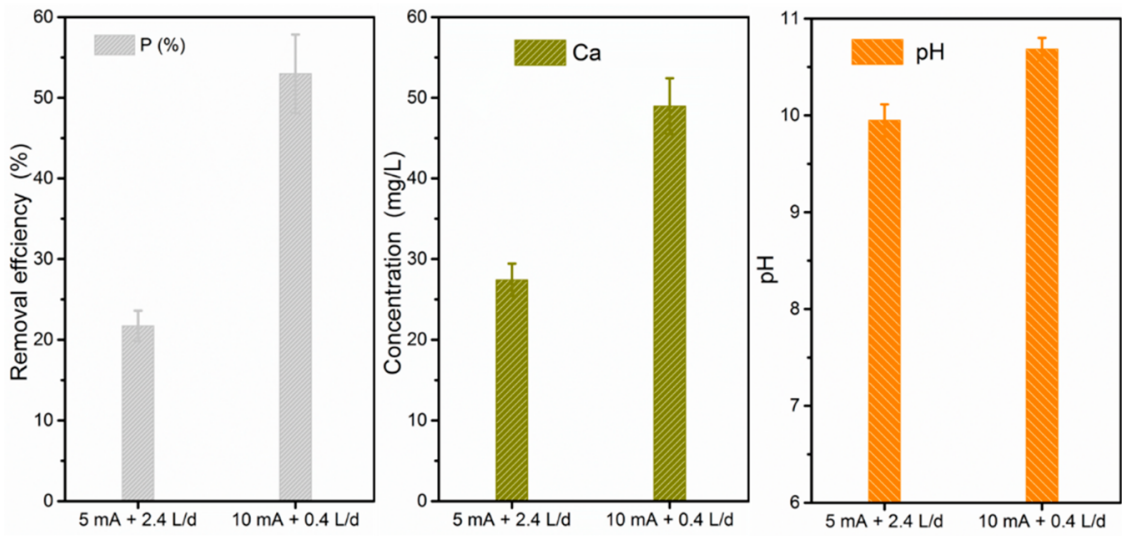

Figure 5. Efficiency of the $\mathrm{CaCO}_{3}$ packed electrochemical precipitation toward low phosphate-containing solutions. Conditions: particle size of 1$2 \mathrm{~mm}$. The feed solutions were synthetic solutions containing $10 \mathrm{mM} \mathrm{Na}_{2} \mathrm{SO}_{4}$ and $1.0 \mathrm{mg} / \mathrm{L} \mathrm{PO}_{4}-\mathrm{P}$.

$\mathrm{L} / \mathrm{d}$, to $61 \%$ at $1.2 \mathrm{~L} / \mathrm{d}$, and down to $28 \%$ at $2.4 \mathrm{~L} / \mathrm{d}$. With a lower feed rate, the feed solution has a longer hydraulic retention time (HRT) in the electrochemical precipitation column, resulting in a high calcium concentration in the reactor solution. The electrolysis current and time determine the electrochemical release of calcium ions from $\mathrm{CaCO}_{3}$ particles. As a result, a higher removal of phosphate is expected with a lower feed rate.

The effluent $\mathrm{Ca}$ concentration confirms the effect of feed rate. We can see from Figure 4 that the effluent $\mathrm{Ca}$ concentration at $0.4 \mathrm{~L} / \mathrm{d}(53 \mathrm{mg} / \mathrm{L})$ was significantly higher than that at $0.8 \mathrm{~L} / \mathrm{d}(22 \mathrm{mg} / \mathrm{L})$. For the highest feed rate $(2.4$ $\mathrm{L} / \mathrm{d}$ ) we tested, the effluent calcium concentration was $13 \mathrm{mg} /$ $\mathrm{L}$, which is indeed lower than that at $1.2 \mathrm{~L} / \mathrm{d}(19 \mathrm{mg} / \mathrm{L})$. However, the effluent $\mathrm{Ca}$ concentrations at $1.2 \mathrm{~L} / \mathrm{d}$ and $0.8 \mathrm{~L} /$ d $(22 \mathrm{mg} / \mathrm{L})$ were similar, which points out the interactive effects of feed rate on the release of $\mathrm{Ca}^{2+}$ and the consumption of released $\mathrm{Ca}^{2+}$. On the one hand, a lower feed rate results in more release of $\mathrm{Ca}^{2+}$. On the other hand, a lower feed rate results in enhanced precipitation of released $\mathrm{Ca}^{2+}$ with phosphate and carbonate due to increased retention time.

The normalized specific energy consumption was comparable $(31 \pm 2 \mathrm{kWh} / \mathrm{kg} \mathrm{P})$ among the feed rates of $2.4,1.2$, and $0.8 \mathrm{~L} / \mathrm{d}$. For the lowest feed rate $(0.4 \mathrm{~L} / \mathrm{d})$, the specific energy consumption was $61 \mathrm{kWh} / \mathrm{kg} \mathrm{P}$. In practical applications, we need to create a balance between the removal efficiency and the feed rate. A lower rate means a higher removal efficiency but a longer HRT, whereas a higher feed rate means a shorter treatment time but relatively lower removal efficiency. Nonetheless, the needed retention time in the current system is relatively low, compared with a previous electrochemical system without the use of $\mathrm{CaCO}_{3}$ particles, ${ }^{23} 0.7-4.2 \mathrm{~h}$ vs $\sim 24$ $h$, yet the phosphate removal efficiency was comparable and even higher. We suggest a feed rate of $1.2 \mathrm{~L} / \mathrm{d}$ for real applications as a satisfactory removal efficiency (61\%), a low HRT $(2.1 \mathrm{~h})$, and a low energy consumption $(29 \mathrm{kWh} / \mathrm{kg} \mathrm{P})$ were achieved at this feed rate.

Calcium lons Instead of $\mathrm{CaCO}_{3}$ Particles (No Bed). To further check the function of the packed $\mathrm{CaCO}_{3}$ bed, we performed control experiments without using $\mathrm{CaCO}_{3}$ particles. Alternatively, calcium ions were supplied in the feed solution. While we provided the feed solution with a high calcium concentration $(40 \mathrm{mg} / \mathrm{L})$, which was even higher than the released calcium ions $(28 \mathrm{mg} / \mathrm{L})$ in the absence of phosphate under standard conditions (Figure 2), the removal of phosphate was much lower than that with $\mathrm{CaCO}_{3}$ particles fully packed in the column (Figure S3). In the absence of $\mathrm{CaCO}_{3}$ particles, the removal of phosphate will depend on its precipitation with calcium ions mainly on the cathode surface, as reported in electrochemical $\mathrm{P}$ removal without the use of $\mathrm{CaCO}_{3}$ solids. ${ }^{23}$ In the bulk solution, due to the recombination of anodically produced $\mathrm{H}^{+}$with cathodically formed $\mathrm{OH}^{-}$(eq 3 ) and the consumption of $\mathrm{OH}^{-}$by calcium phosphate precipitation, the solution $\mathrm{pH}$ will decrease. ${ }^{23}$ Indeed, the effluent $\mathrm{pH}$ in the absence of $\mathrm{CaCO}_{3}$ particles $(\mathrm{pH}$ 7.3) is much lower than that with $\mathrm{CaCO}_{3}$ solids packed in the column ( $\mathrm{pH}$ 9.8). When the feed rate was reduced and the applied current was increased, the $\mathrm{P}$ removal efficiency increased from $13 \%$ to $33 \%$, yet it was still much lower than that of the $\mathrm{CaCO}_{3}$ packed column under similar conditions $(\sim 90 \%)$ as was the effluent $\mathrm{pH}$ (7.1). Again, the results confirmed the multiple functions of the packed $\mathrm{CaCO}_{3}$ granules: (1) provide $\mathrm{Ca}^{2+},(2)$ limit the recombination of $\mathrm{H}^{+}$with $\mathrm{OH}^{-}$, (3) enhance calcium phosphate precipitation, and (4) retain precipitates.

Efficiency for Low Phosphate-Containing Solutions and Real Domestic Wastewater. We further investigated the performance of the electrochemical precipitation column for low $\mathrm{P}$ streams, as an application of this process toward posttreatment. The typical effluent $\mathrm{P}$ concentration in the wastewater treatment plant is around $1.0 \mathrm{mg} / \mathrm{L}$. Due to strict legislation requirements, some wastewater treatment plants may need to update their process. We found that the $\mathrm{CaCO}_{3}$ packed electrochemical precipitation column is also suitable for low P streams. Still, this is not caused by adsorption, because the removal of phosphate is negligible in an open circuit. The precipitation potential of a specific mineral is affected by the concentration of the associated lattice ion, temperature, and solution $\mathrm{pH}$, which can be evaluated through the calculation of the saturation index (SI). ${ }^{26}$ The low $\mathrm{P}$ concentration might make it difficult to have $\mathrm{P}$ removed by precipitation. However, the low phosphate-containing solution is still highly saturated with respect to hydroxyapatite $\left(\mathrm{HAP}, \mathrm{SI}_{\mathrm{HAP}}=13\right)$ in the precipitation column (Text S2) thanks to the release of $\mathrm{Ca}^{2+}$ and the increase of $\mathrm{pH}$. In addition, the $\mathrm{CaCO}_{3}$ particles assist calcium phosphate precipitation by lowering the induction time for precipitation. ${ }^{27}$ As a result, the $\mathrm{P}$ removal efficiency reached $22 \%$ even though the initial concentration was just 1.0 $\mathrm{mg} / \mathrm{L}$ (Figure 5). The P removal efficiency could be further enhanced by lowering the feed rate and increasing the applied current. About $53 \%$ of the phosphate was removed at $10 \mathrm{~mA}$ 
with a feed rate of $0.4 \mathrm{~L} / \mathrm{d}$. We also noticed that the effluent Ca concentration was higher when treating the low P streams $(27 \mathrm{mg} / \mathrm{L}$, Figure 5) than that when treating a higher $\mathrm{P}$ concentration stream $(15 \mathrm{mg} / \mathrm{L}$, Figure 3$)$ under standard conditions $(5 \mathrm{~mA}, 2.4 \mathrm{~L} / \mathrm{d})$, which is due to the reduced consumption of released calcium ions that leaves more calcium ions in the effluent. The effluent $\mathrm{pH}$ was 9.9 under standard conditions $(5 \mathrm{~mA}, 2.4 \mathrm{~L} / \mathrm{d})$ and was increased to 10.7 at an increased current $(10 \mathrm{~mA})$ with a lower feed rate $(0.4 \mathrm{~L} / \mathrm{d})$.

We then treated real wastewater with the electrochemical precipitation column. The initial $\mathrm{P}$ concentration in the wastewater was about $3 \mathrm{mg} / \mathrm{L}$, which was lower than the wastewater we sampled previously. ${ }^{13}$ This was probably due to the frequent rain in the local area before sampling was conducted. Still, as shown in Figure S4, about 16\% of the P was removed under standard conditions, and $43 \% \mathrm{P}$ was removed at optimized conditions $(10 \mathrm{~mA}, 0.4 \mathrm{~L} / \mathrm{d})$. The $\mathrm{pH}$ of the wastewater increased from 7.7 to 8.5 after treatment. The lower increase in solution $\mathrm{pH}$ in real wastewater than that in synthetic solutions is probably due to the buffers presented in the domestic wastewater. This is an advantage in the real application as the $\mathrm{pH}$ of treated wastewater should not be higher than 9.0. This preliminary result demonstrates the feasibility of applying this system for complicated real wastewater.

Long-Term Performance. We further performed a longterm evaluation of this electrochemical precipitation column in view of its potential application. We ran the system for 125 days under optimized conditions based on the investigation of different parameters that we have discussed here. The results are summarized in Figure 6. It was found that in the initial 40

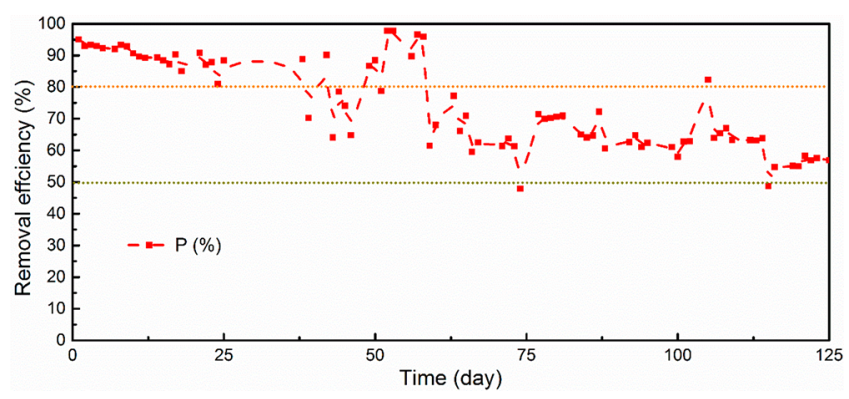

Figure 6. $\mathrm{P}$ removal efficiency of the $\mathrm{CaCO}_{3}$ packed electrochemical precipitation in long-term operation. Conditions: particle size, $<0.5$ $\mathrm{mm}$; current, $5 \mathrm{~mA}$ (current density $3.5 \mathrm{~A} / \mathrm{m}^{2}$ ); feed rate, $0.4 \mathrm{~L} / \mathrm{d}$. Feed solution contains $10 \mathrm{mM} \mathrm{Na}_{2} \mathrm{SO}_{4}$ and $0.6 \mathrm{mM} \mathrm{PO}_{4}-\mathrm{P}$ with an initial $\mathrm{pH}$ of 7.5 .

days, the $P$ removal efficiency was maintained at $90 \pm 5 \%$. Thereafter, the removal efficiency decreased slightly but was still around $60 \%$ until around the 110th day. Even after more than 125 days of operation, the column still achieved a $\mathrm{P}$ removal efficiency of more than $50 \%$. These results confirmed that the system can work quite well in long-term operation with little maintenance (clean or replace the effluent tube).

Calcium Phosphate Presents Both on the Cathode and the $\mathrm{CaCO}_{3}$ Particles. To understand where calcium phosphate precipitates, we analyzed the precipitates on the $\mathrm{CaCO}_{3}$ solids and the electrodes by considering the experiments performed under standard conditions (1-2 mm particle size; $12-13 \mathrm{~cm}$ bed, $5 \mathrm{~mA}, 2.4 \mathrm{~L} / \mathrm{d}$ ) as examples. The analysis of the elemental composition of the $\mathrm{CaCO}_{3}$ particles showed $\mathrm{P}$ to be present on the used particles (Table S1). The detection of $\mathrm{P}$ on the used $\mathrm{CaCO}_{3}$ particles indicates that part of the $\mathrm{P}$ in the feed solution is removed by (heterogeneous) precipitation on the $\mathrm{CaCO}_{3}$ particles. We then used acid $(20 \mathrm{~mL}, 1 \mathrm{M}$ $\left.\mathrm{HNO}_{3}\right)$ to dissolve the precipitates on the electrodes and analyzed the compositions of the acidic solutions. The $\mathrm{Ca}$ and $\mathrm{P}$ concentrations detected in the acidic solution from the cathode were 170 and 42 times higher than those in the acidic solution used for the anode, respectively (Table S2). This confirms the precipitation of calcium phosphate on the cathode but not on the anode, due to local high $\mathrm{pH}$ and low $\mathrm{pH}$, respectively. In conclusion, in the $\mathrm{CaCO}_{3}$ packed electrochemical precipitation column, calcium phosphate precipitates both on the cathode and on the $\mathrm{CaCO}_{3}$ particles.

\section{OUTLOOK}

We experimentally investigated the principle and demonstrated the efficiency and the stability of the $\mathrm{CaCO}_{3}$ packed electrochemical precipitation column toward phosphate removal. One unaddressed question that remains is how can the removed phosphate be reused? Indeed, unlike previously reported systems where we can collect calcium phosphate solids from the cathode, in the current system, the calcium phosphate precipitates were mixed with packed calcium carbonate particles. This makes the collection of calcium phosphate difficult. However, we may not need to separate the calcium phosphate solids from the mixture. Given the fact that $\mathrm{CaCO}_{3}$ solids, in general, are more soluble than calcium phosphate solids, it may be possible to convert most of the $\mathrm{CaCO}_{3}$ in the column to calcium phosphate. Thus we can collect the whole solids from the precipitation column and replace them with new $\mathrm{CaCO}_{3}$ solids. The collected solids may be used either in the production of $\mathrm{P}$ fertilizer or directly as fertilizer. Alternatively, the separation of calcium phosphate precipitates with the packed $\mathrm{CaCO}_{3}$ solids could be enhanced by an improved cell configuration, for instance, by putting the anode in a porous $\mathrm{CaCO}_{3}$ container. In this design, the reaction of $\mathrm{H}^{+}$with the $\mathrm{CaCO}_{3}$ particles is physically separated from the calcium phosphate precipitation on the cathode and in the bulk solution. Hopefully, this design can be made into reality in our future studies. Given the relatively low energy consumption $(29-61 \mathrm{kWh} / \mathrm{kg} \mathrm{P})$ and the fact that calcium carbonate is a cheap material (here, it is a byproduct from a water softening process), the $\mathrm{CaCO}_{3}$ packed electrochemical precipitation column may offer a robust yet highly stable and efficient system to deal with $\mathrm{P}$ containing streams at various concentrations.

\section{ASSOCIATED CONTENT}

\section{Supporting Information}

The Supporting Information is available free of charge on the ACS Publications website at DOI: 10.1021/acs.est.9b03795.

Solid characterization, calculation of supersaturation index for a low phosphate-containing solution, XRD pattern of $\mathrm{CaCO}_{3}$ particles, effects of particle size of $\mathrm{CaCO}_{3}$ solids on the removal of $\mathrm{P}$, effluent $\mathrm{Ca}$ concentration and $\mathrm{pH}$, efficiency of the $\mathrm{CaCO}_{3}$ packed electrochemical precipitation towards real wastewater, elemental composition of fresh (unused) and used $\mathrm{CaCO}_{3}$ particles, and $\mathrm{Ca}, \mathrm{Mg}$, and $\mathrm{P}$ concentrations in the acidic solution used for dissolving the precipitates on the electrodes (PDF) 


\section{AUTHOR INFORMATION}

\section{Corresponding Authors}

*E-mail: yang.lei@wur.nl.

*E-mail: renata.vanderweijden@wur.nl.

ORCID $\odot$

Yang Lei: 0000-0003-0709-4743

\section{Notes}

The authors declare no competing financial interest.

\section{ACKNOWLEDGMENTS}

This work was performed in the cooperation framework of Wetsus, European Centre of Excellence for Sustainable Water Technology (www.wetsus.eu). Wetsus is cofunded by the Dutch Ministry of Economic Affairs and Ministry of Infrastructure and Environment, the European Union Regional Development Fund, the Province of Fryslân, and the Northern Netherlands Provinces. This research has received funding from the European Union's Horizon 2020 research and innovation programme under the Marie Skłodowska-Curie grant agreement No 665874. We are grateful to the participants of the research theme "Resource Recovery" for fruitful discussions and financial support.

\section{REFERENCES}

(1) Karl, D. M. Aquatic ecology: Phosphorus, the staff of life. Nature 2000, 406 (6791), 31.

(2) Jasinski, S. M., Phosphate rock. In Mineral Commodity Summaries; United States Geological Survey: 2018.

(3) Cordell, D.; Drangert, J.-O.; White, S. The story of phosphorus: Global food security and food for thought. Global Environmental Change 2009, 19 (2), 292-305.

(4) Elser, J.; Bennett, E. Phosphorus cycle: a broken biogeochemical cycle. Nature 2011, 478 (7367), 29-31.

(5) Mayer, B. K.; Baker, L. A.; Boyer, T. H.; Drechsel, P.; Gifford, M.; Hanjra, M. A.; Parameswaran, P.; Stoltzfus, J.; Westerhoff, P.; Rittmann, B. E. Total value of phosphorus recovery. Environ. Sci. Technol. 2016, 50 (13), 6606-20.

(6) Morse, G.; Brett, S.; Guy, J.; Lester, J. Phosphorus removal and recovery technologies. Sci. Total Environ. 1998, 212 (1), 69-81.

(7) Desmidt, E.; Ghyselbrecht, K.; Zhang, Y.; Pinoy, L.; Van der Bruggen, B.; Verstraete, W.; Rabaey, K.; Meesschaert, B. Global Phosphorus Scarcity and Full-Scale P-Recovery Techniques: A Review. Crit. Rev. Environ. Sci. Technol. 2015, 45 (4), 336-384.

(8) Le Corre, K. S.; Valsami-Jones, E.; Hobbs, P.; Parsons, S. A. Phosphorus recovery from wastewater by struvite crystallization: A review. Crit. Rev. Environ. Sci. Technol. 2009, 39 (6), 433-477.

(9) Hao, X. D.; Wang, C. C.; Lan, L.; van Loosdrecht, M. C. Struvite formation, analytical methods and effects of $\mathrm{pH}$ and $\mathrm{Ca}^{2+}$. Water Sci. Technol. 2008, 58 (8), 1687-92.

(10) Hovelmann, J.; Putnis, C. V. In situ nanoscale imaging of struvite formation during the dissolution of natural brucite: implications for phosphorus recovery from wastewaters. Environ. Sci. Technol. 2016, 50 (23), 13032-13041.

(11) Hao, X.; Wang, C.; van Loosdrecht, M. C.; Hu, Y. Looking beyond struvite for P-recovery. Environ. Sci. Technol. 2013, 47 (10), 4965-6.

(12) Tervahauta, T.; van der Weijden, R. D.; Flemming, R. L.; Hernandez Leal, L.; Zeeman, G.; Buisman, C. J. Calcium phosphate granulation in anaerobic treatment of black water: a new approach to phosphorus recovery. Water Res. 2014, 48, 632-42.

(13) Lei, Y.; Remmers, J.; van der Weijden, R. D.; Saakes, M.; Buisman, C. J. Is there a precipitation sequence in municipal wastewater induced by electrolysis? Environ. Sci. Technol. 2018, 52 (15), 8399-8407.
(14) Randall, D. G.; Krähenbühl, M.; Köpping, I.; Larsen, T. A.; Udert, K. M. A novel approach for stabilizing fresh urine by calcium hydroxide addition. Water Res. 2016, 95, 361-369.

(15) Bouzas, A.; Martí, N.; Grau, S.; Barat, R.; Mangin, D.; Pastor, L. Implementation of a global P-recovery system in urban wastewater treatment plants. J. Cleaner Prod. 2019, 227, 130-140.

(16) Meyer, G.; Frossard, E.; Mäder, P.; Nanzer, S.; Randall, D. G.; Udert, K. M.; Oberson, A. Water soluble phosphate fertilizers for crops grown in calcareous soils-an outdated paradigm for recycled phosphorus fertilizers? Plant Soil 2018, 424 (1-2), 367-388.

(17) Brillas, E.; Sirés, I.; Oturan, M. A. Electro-Fenton process and related electrochemical technologies based on Fenton's reaction chemistry. Chem. Rev. 2009, 109 (12), 6570-6631.

(18) Radjenovic, J.; Sedlak, D. L. Challenges and opportunities for electrochemical processes as next-generation technologies for the treatment of contaminated water. Environ. Sci. Technol. 2015, 49 (19), $11292-302$

(19) Christiaens, M. E. R.; Gildemyn, S.; Matassa, S.; Ysebaert, T.; De Vrieze, J.; Rabaey, K. Electrochemical ammonia recovery from source-separated urine for microbial protein production. Environ. Sci. Technol. 2017, 51 (22), 13143-13150.

(20) Tarpeh, W. A.; Barazesh, J. M.; Cath, T. Y.; Nelson, K. L. Electrochemical stripping to recover nitrogen from source-separated urine. Environ. Sci. Technol. 2018, 52 (3), 1453-1460.

(21) Lei, Y.; Remmers, J. C.; Saakes, M.; van der Weijden, R. D.; Buisman, C. J. N. Influence of cell configuration and long-term operation on electrochemical phosphorus recovery from domestic wastewater. ACS Sustainable Chem. Eng. 2019, 7 (7), 7362-7368.

(22) Lei, Y.; Hidayat, I.; van der Weijden, R. D.; Saakes, M.; Buisman, C. J. Fate of calcium, magnesium and inorganic carbon in electrochemical phosphorus recovery from domestic wastewater. Chem. Eng. J. 2019, 362, 453-459.

(23) Lei, Y.; Song, B.; van der Weijden, R. D.; Saakes, M.; Buisman, C. J. Electrochemical induced calcium phosphate precipitation: Importance of local pH. Environ. Sci. Technol. 2017, 51 (19), 11156-11164.

(24) Rau, G. H. Electrochemical splitting of calcium carbonate to increase solution alkalinity: Implications for mitigation of carbon dioxide and ocean acidity. Environ. Sci. Technol. 2008, 42 (23), 89358940.

(25) Wang, L.; Ruiz-Agudo, E.; Putnis, C. V.; Menneken, M.; Putnis, A. Kinetics of Calcium Phosphate Nucleation and Growth on Calcite: Implications for Predicting the Fate of Dissolved Phosphate Species in Alkaline Soils. Environ. Sci. Technol. 2012, 46 (2), 834-842.

(26) Song, Y.; Hahn, H. H.; Hoffmann, E. Effects of solution conditions on the precipitation of phosphate for recovery: A thermodynamic evaluation. Chemosphere 2002, 48 (10), 1029-1034.

(27) Song, Y.; Weidler, P. G.; Berg, U.; Nuesch, R.; Donnert, D. Calcite-seeded crystallization of calcium phosphate for phosphorus recovery. Chemosphere 2006, 63 (2), 236-43. 